\title{
Naringenin Regulates CFTR Activation and Expression in Airway Epithelial Cells
}

\author{
Rui Shia,b,c Zi-Ting Xiao ${ }^{a, b, c}$ Yi-Jun Zheng ${ }^{c} \quad$ Yi-Lin Zhang ${ }^{c}$ Jia-Wen Xuc \\ Jie-Hong Huang ${ }^{c}$ Wen-Liang Zhou ${ }^{c}$ Pei-Bo Lia, ${ }^{a, b}$ Wei-Wei Su, ${ }^{a, b, c}$ \\ aGuangdong Engineering \& Technology Research Center for Quality and Efficacy Re-evaluation of \\ Post-market Traditional Chinese Medicine, School of Life Sciences, Sun Yat-sen University, Guangzhou; \\ bState Key Laboratory of Biocontrol and Guangdong Provincial Key Laboratory of Plant Resources, \\ School of Life Sciences, Sun Yat-sen University, Guangzhou; 'School of Life Sciences, Sun Yat-sen \\ University, Guangzhou, China
}

\section{Key Words}

Naringenin • Airway epithelium $\bullet \mathrm{CFTR} \cdot \mathrm{Cl}^{-}$secretion $\bullet$ Traditional Chinese medicine

\begin{abstract}
Background/Aims: Sputum symptoms are commonly seen in the elderly. This study aimed to identify an efficacious expectorant treatment stratagem through evaluating the secretionpromoting activation and cystic fibrosis transmembrane conductance regulator (CFTR) expression of the bioactive herbal monomer naringenin. Methods: Vectorial $\mathrm{Cl}^{-}$transport was determined by measuring short-circuit current $\left(I_{\mathrm{SC}}\right)$ in rat airway epithelium. CAMP content was measured by ELISA in primary cultured epithelial cells and Calu-3 cells. CFTR expression in Calu-3 cells was determined by qPCR. Results: Addition of naringenin to the basolateral side of the rat airway led to a concentration-dependent sustained increase in $I_{\mathrm{SC}}$. The current was suppressed when exposed to $\mathrm{Cl}^{-}$-free solution or by bumetanide, $\mathrm{BaCl}_{2^{\prime}}$ and DPC but not by DIDS and IBMX. Forskolin-induced $I_{\text {SC }}$ increase and CFTRinh-172/MDL-12330A-induced $I_{\text {sC }}$ inhibition were not altered by naringenin. Intracellular CAMP content was significantly increased by naringenin. With lipopolysaccharide stimulation, CFTR expression was significantly reduced, and naringenin dose-dependently enhanced CFTR mRNA expression. Conclusion: These results demonstrate that naringenin has the ability to stimulate $\mathrm{Cl}^{-}$secretion, which is mediated by CFTR through a signaling pathway by increasing CAMP content. Moreover, naringenin can increase CFTR expression when organism CFTR expression is seriously hampered. Our data suggest a potentially effective treatment strategy for sputum.
\end{abstract}

(C) 2017 The Author(s)

Published by S. Karger AG, Basel

\section{Introduction}

It is commonly known that airway surface liquid (ASL) comprises a mucus layer (ML) and a periciliary fluid layer (PCL). The superficial ML overlies the PCL, which contacts airway surface epithelial cells [1]. The ML consists of a large amount of water, salt and proteins

Wei-Wei Su

and Wen-Liang Zhou
School of Life Sciences, Sun Yat-sen University

No. 135, Xingangxi Street, Guangzhou (China)

Tel. +86 20 84110808; Tel. +86 20 39386076, E-Mail Issswwhk@gmail.com 
Shi et al.: Effect of Naringenin on CFTR

secreted by submucosal gland serum cells and surface epithelial goblet cells. It determines sputum viscosity to trap dust in the airway. The PCL, secreted by epithelial cells and submucosal glands, has lower viscosity than the ML due to higher water content and acts as the medium for cilia clearing dust and germs from the respiratory tract. The depth, composition and viscosity of ASL are important determinants of mucociliary clearance, bactericidal activity, and the functions of epithelial and immune cells [1]. Ion channels, transporters and pumps are located on apical and basolateral membranes in certain strategies that determine the absorption and secretion of electrolytes and the fluid content in epithelial cells. Particularly, airway epithelial $\mathrm{Cl}^{-}$channels, such as cystic fibrosis transmembrane conductance regulator (CFTR), are crucial factors in the regulation of electrolytes and fluid secretion across the respiratory system [2]. CFTR abnormality is considered to be the main cause of cystic fibrosis (CF), which is an inherited disorder widespread among the white race [3]. A lack of CFTR leads to weak electrolyte and fluid secretion, thus leading to a decreased PCL $[4,5]$. Therefore, the epithelial cilia cannot swing to expel sputum from the airway, resulting in sputum increase. Hence, drugs with regulatory effects on CFTR-mediated $\mathrm{Cl}^{-}$secretion and channel expression may relieve the symptoms of the disease to some extent.

Naringenin is a type of dihydroflavone found in our regular diet and is mainly derived from Exocarpium Citri grandis (Huajuhong in Chinese, the dried unripe fruit peel of Citrus grandis 'Tomentosa' or Citrus grandis (L.) Osbeck), which has been a well-known traditional Chinese medicine to treat cough and sputum for thousands of years [6]. As an additive, naringenin can be incorporated into foods or beverages to inhibit ACAT activity, inhibit macrophage-lipid complex accumulation, and prevent or treat hepatic diseases [7]. It has been demonstrated that naringenin exhibits antioxidative, anti-inflammatory, anti-asthmatic and expectorant effects both in vitro and in vivo $[6,8,9]$. A previous study demonstrated that naringenin could significantly attenuate human neutrophil elastase (HNE)-induced MUC5AC secretion in HBE16 human airway epithelial cells by inhibiting the activity of NF- $\kappa$ B via EGFR-PI3K-Akt/ERK MAPKinase signaling pathways [10] and dose dependently enhancing mucociliary velocity and phenol red secretion into the airway [6]. This evidence showed that naringenin could decrease the viscosity of mucus and enhance mucociliary clearance by stimulating the volume of airway secretions. Nonetheless, whether naringenin improves ASL volume secretion in airway epithelial cells mediated by CFTR remains unclear. Therefore, to find curative potential for medication of sputum and other analogous diseases, the current study is designed to investigate the regulatory mechanism of naringenin.

\section{Materials and Methods}

\section{Animal preparation}

After one week of adjustment to the new environment, 100-200 g male and female Sprague-Dawley rats were killed via $\mathrm{CO}_{2}$ asphyxiation and used to measure transepithelial $I_{\mathrm{SC}^{\prime}}$, culture primary epithelial cells and quantify cyclic adenosine monophosphate (cAMP) content. The rats were purchased from Guangdong Medical Laboratory Animal Center (Guangdong, China), housed in a temperature- and humidity-controlled room in a 12 hour light/dark cycle and fed a standard laboratory diet and fresh water. All experimental procedures were based on the guiding principles for the care and use of animals approved by the Animal Care and Use Committee of the School of Life Sciences, Sun Yat-sen University, PR China. Adequate measures were taken to minimize the pain of the animals.

\section{Cell culture}

Calu-3 cells (a human lung adenocarcinoma epithelial cell line) were gifts from Dr. Wing-Hung Ko at The Chinese University of Hong Kong, HK, China. Cells were cultured with Dulbecco's modified Eagle's medium/F12 (DMEM/F12) (Gibco, USA) supplemented with 10\% fetal bovine serum (HyClone, Australian), 1\% MEM NEAA (Gibco, USA), and $100 \mathrm{U} / \mathrm{ml}$ penicillin-streptomycin solution (HyClone, USA) in a humidified atmosphere of $5 \% \mathrm{CO}_{2}$ at $37^{\circ} \mathrm{C}$.

\section{KARGER}


Shi et al.: Effect of Naringenin on CFTR

Primary rat airway epithelial cells were digested for 16 hours from acutely dissociated rat airway using trypsin-EDTA (0.25\%) and maintained in Keratinocyte Serum Free Medium (K-SFM) (Gibco, USA) supplemented with $10 \%$ fetal bovine serum (HyClone, Australian) and $100 \mathrm{U} / \mathrm{ml}$ penicillin-streptomycin solution (HyClone, USA) in a humidified atmosphere of $5 \% \mathrm{CO}_{2}$ at $37^{\circ} \mathrm{C}$.

\section{Chemicals}

Lipopolysaccharides (LPS), naringenin, diphenylamine-2-carboxylic acid (DPC), 4, 4'-diisothiocyanatostilbene-2, 2'-disulfonic acid (DIDS), 4-[[4-0xo-2-thioxo-3-[3-trifluoromethyl)phenyl]-5-thiazolidinylidene]methyl]benzoic acid (CFTRinh-172), N-(cis-2-phenyl-cyclopentyl)azacyclotridecan-2-imine-hydrochloride (MDL-12330A) and 3-isobutyl-1-methylxanthine (IBMX) were purchased from Sigma-Aldrich (St. Louis, MO, USA). All the above reagents were dissolved in dimethyl sulfoxide (DMSO). The final concentration of DMSO was $0.1 \%$, which had no significant effects on the $I_{\mathrm{SC}}$ or CFTR expression.

\section{$I_{\mathrm{SC}}$ measurements}

The airway segment (7-8 $\mathrm{mm}$ in length) used for $I_{\mathrm{SC}}$ measurement and cell culture was isolated from the main trachea, starting from a location $1 \mathrm{~mm}$ under the thyroid. To avoid epithelial damage, blunt separation rather than hard tearing was applied. After removing the blood vessels and connective tissue, the tracheas were cut into $3 \mathrm{~mm}$ segments, and the ventral side of the trachea was cut to expose the lumen. Airway tissue was dipped in Kerbs-Henseleit (K-H) solution containing (in mM) $117 \mathrm{NaCl}, 4.7 \mathrm{KCl}, 1.2 \mathrm{KH}_{2} \mathrm{PO}_{4}, 25$ $\mathrm{NaHCO}_{3}, 1.2 \mathrm{MgSO}_{4}, 2.56 \mathrm{CaCl}_{2}$, and 11.1 glucose $\left(\mathrm{pH} 7.4\right.$ ) warmed to $37^{\circ} \mathrm{C}$ and ventilated in $95 \% \mathrm{O}_{2}$ and $5 \%$ $\mathrm{CO}_{2}$. In ion substitution experiments, $\mathrm{HCO}_{3}{ }^{-}$was substituted by $\mathrm{HEPES}$, and $\mathrm{Cl}^{-}$was substituted by gluconate. $\mathrm{HCO}_{3}{ }^{-}$free solution was ventilated in $100 \% \mathrm{O}_{2}$. To control the solution effects, fluid offsets were used to adjust the fluid resistance to 0 [11]. When short-circuit current measurements were taken in different ionic composition solutions, new tissue was used each time, and the bathing solution was not changed with the same tissue. The fluid resistance of the different solutions was adjusted to 0 before the tissue was mounted. Therefore, fluid resistance did not affect the accuracy of the experiment. After adjusting the fluid resistance to 0 , tissue samples were mounted on a Ussing chamber with a $0.03 \mathrm{~cm}^{2}$ circular internal area, using vertical force to avoid friction with the epithelium and affecting the function. The diameter of Ussing chamber's aperture was $1.96 \mathrm{~mm}$, which was greater than the space enclosed by the adjacent cartilage rings, and thus, the cartilage rings were seen in the mounted segment. The airway epithelial cells located on the surface of the cartilage ring segment showed no functional differences from that on the surface of the muscle segment. Thus, the cartilage rings presented in the mounted segment did not influence $I_{\mathrm{SC}}$ measurement. Calu- 3 cells grown on transwell inserts $(0.4 \mu \mathrm{m}$ pore size, $12 \mathrm{~mm}$ diameter) were incubated with DMEM/F12 for a fortnight. A confluent Calu-3 cell monolayer was used to measure $I_{\mathrm{SC}}$. After the transepithelial potential difference (PD) was locked at $0 \mathrm{mV}$, the $I_{\mathrm{SC}}$ was recorded by a voltage-current clamp amplifier (VCC MC6, Physiologic instrument, San Diego, CA) and then exhibited by a BL-420E signal collection and analysis system (Chengdu Techman Software Co. Ltd., China). Change in the current per unit area $\left(\mu \mathrm{A} / \mathrm{cm}^{2}\right)$ normalized the $I_{\mathrm{sC}}$ variation. When the current flowed from the mucosal to serosal side, the $I_{\mathrm{sC}}$ value was expressed as positive [12].

\section{Immunofluorescence}

Rat primary airway epithelial cells grown on coverslips were incubated with K-SFM for 3 days. After being fixed with $4 \%$ paraformaldehyde, the cells were permeated with $0.3 \%$ Triton and 5\% BSA mixed solution for 1 hour at $25^{\circ} \mathrm{C}$. The cells were incubated with smooth muscle antibody (SMA) and keratin antibody for 2 hours at room temperature. Following three washes with phosphate-buffered saline (PBS), the cells were incubated with fluorescein-conjugated antibody to mark target cells and visualized using microscopy.

\section{Measurement of intracellular cAMP concentrations}

Measurement of the cAMP concentration in airway tissue might include the cAMP of other cells at the same time, which affects the accuracy of the experiment. Therefore, we used primary rat airway epithelial cells to measure cAMP content and Calu-3 cells to further verify the results.

The cytosolic cAMP content was measured via enzyme linked immunosorbent assay (ELISA). After primary epithelial cells were cultured in six-well plates for 3 days, the degree of confluence was approximately one hundred percent [13]. The cells were treated with DMSO, naringenin, IBMX, IBMX with naringenin, or 
Shi et al.: Effect of Naringenin on CFTR

IBMX with forskolin, for 20 min. Calu-3 cells were treated in the same way. The cAMP content was assayed using a Mouse/Rat cAMP Assay Kit (R\&D systems, USA). The protein content was determined with a BCA Protein Assay Kit (Beyotime, China). The concentration of cytosolic cAMP is expressed in picomoles per milligram of protein.

\section{RNA isolation and reverse transcription}

Calu-3 cells grown in six-well plates were induced with or without $10 \mu \mathrm{g} / \mathrm{ml} \mathrm{LPS}$ and treated with $0.1 \%$ DMSO (control group) or naringenin $(25 \mu \mathrm{M}, 50 \mu \mathrm{M}$ and $100 \mu \mathrm{M})$ for 8 hours to test CFTR mRNA expression. In advance of the experiment, an MTT assay had been performed to certify that the drugs had no effect on Calu-3 cell viability within 8 hours.

Total RNA was extracted from Calu-3 cells using RNAiso Plus (TaKaRa, Japan), and reverse transcribed with a GoScript ${ }^{\mathrm{TM}}$ Reverse Transcription System (Promega, USA). Samples were quantified with a NanoDrop 2000 (Thermo, USA).

\section{Quantitative real-time polymerase chain reaction}

Quantitative real-time polymerase chain reaction (qRT-PCR) was performed to quantitatively determine the mRNA level of CFTR. The gene-specific primers used for qRT-PCR analysis were synthesized by Shanghai Generay Biotech Co., Ltd. (Shanghai, China). Gene-specific primers: CFTR forward 5'-AAG CTG TCA AGC CGT GTT CT-3' and reverse 5'-GAT TAG CCC CAT GAG GAG TG-3'; $\beta$-actin forward 5'-CCT GTA CGC CAA CAC AGT GC-3' and reverse 5'-ATA CTC CTG CTT GCT GAT CC-3'. The reaction was performed using GoTaq ${ }^{\circledR}$ qPCR Master Mix (Promega, USA), with the following cycles: $10 \mathrm{~min}$ at $95^{\circ} \mathrm{C}, 45$ cycles of $10 \mathrm{~s}$ at $95^{\circ} \mathrm{C}, 20 \mathrm{~s}$ at $60^{\circ} \mathrm{C}, 20 \mathrm{~s}$ at $72^{\circ} \mathrm{C}$, one cycle of $5 \mathrm{~s}$ at $95^{\circ} \mathrm{C}, 60 \mathrm{~s}$ at $65^{\circ} \mathrm{C}, 30 \mathrm{~s}$ at $97^{\circ} \mathrm{C}$, and finally, $30 \mathrm{~s}$ at $40^{\circ} \mathrm{C}$. A Roche LightCycle 480 System (Roche, Mannheim, Germany) was used to run the reactions. Measurements were performed in triplicate for one sample and approved if the discrepancy between the threshold value (Ct) was less than 1. To implement a relative expression method, $\beta$-actin was used as an internal control to normalize the data, and the final results are expressed as a percentage of the control group.

\section{Data analysis and statistics}

The data are presented as the mean \pm SEM ( $\mathrm{n}$ is the number of tissue preparations or experiment replications). Statistical significance was determined by Student's t-test. A value of $\mathrm{P}<0.05$ was considered statistically significant.

\section{Results}

\section{Naringenin-induced $I_{\mathrm{SC}}$ response}

A change in $I_{\mathrm{SC}}$ was defined as the maximal rise in $I_{\mathrm{SC}}$ following drug stimulation, and it was normalized to current change per unit area of the airway $\left(\mu \mathrm{A} / \mathrm{cm}^{2}\right)$. The basal $I_{\mathrm{sC}}$ in isolated rat airway tissue was $8.86 \pm 0.72 \mu \mathrm{A} / \mathrm{cm}^{2}(\mathrm{n}=4)$. Naringenin $(100 \mu \mathrm{M})$ applied to the apical side of rat airway tissue could not cause a change in $I_{\mathrm{SC}}$ (Fig. 1A). However, basolateral application of naringenin at a concentration of $100 \mu \mathrm{M}$ caused an obvious $I_{\mathrm{SC}}$ increase, and then, the $I_{\mathrm{SC}}$ remained stable (Fig. 1B). Furthermore, the augmentation was concentrationdependent (Fig. $1 \mathrm{C}$ ), with an $\mathrm{EC}_{50}$ of approximately $71.49 \pm 10.76 \mu \mathrm{M}$. There was no significant difference in the osmotic pressure before and after naringenin addition. Therefore, the concentration-dependent results shown in Fig. $1 \mathrm{C}$ were not caused by a change in the permeability but by the pharmacodynamic effects of naringenin.

\section{Ionic basis of the naringenin-induced $I_{\mathrm{SC}}$ response}

To investigate the ion species mediating the naringenin-induced $I_{\mathrm{SC}}$, ion substitution experiments (Fig. 2) and $\mathrm{Cl}^{-}$channel blocker tests (Fig. 4) were designed.

To remove $\mathrm{HCO}_{3}{ }^{-}$from the $\mathrm{K}-\mathrm{H}$ solution, $\mathrm{HCO}_{3}{ }^{-}$was substituted with $10 \mathrm{mM}$ HEPES. The solution only slightly suppressed the naringenin-evoked $I_{\mathrm{SC}}$ by $5.12 \%(\mathrm{n}=4)(\mathrm{Fig}$. 2A), while solution without $\mathrm{Cl}^{-}$(the representative salts of gluconate acted as substitutes) restrained the $I_{\mathrm{SC}}$ enhancement by $91.53 \%(\mathrm{n}=4$, P $<0.001$, Fig. 2B). Furthermore, when extracellular 


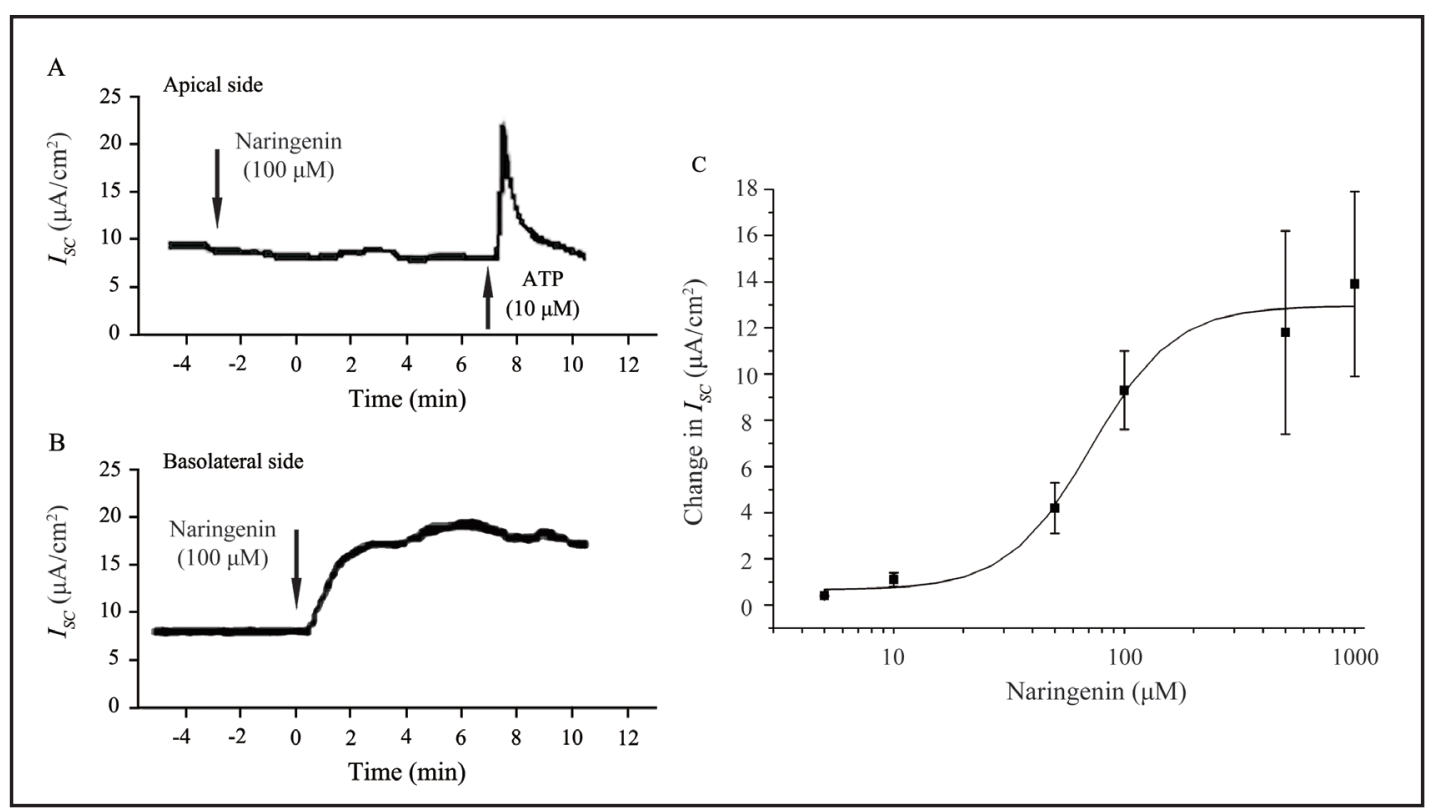

Fig. 1. Effect of naringenin on anion transport across the rat airway. Naringenin $(100 \mu \mathrm{M})$ applied to the apical side of rat airway tissue could not cause a change in $\mathrm{I}_{\mathrm{SC}^{*}}(\mathrm{~A})$. Naringenin $(100 \mu \mathrm{M})$ applied to the basolateral side of rat airway tissue resulted in an increase in $\mathrm{I}_{\mathrm{SC}}(\mathrm{B})$. Different concentrations of naringenin $(5 \mu \mathrm{M}-1000 \mu \mathrm{M})$ stimulated a concentration-dependent $\mathrm{I}_{\mathrm{SC}}$ response on the basolateral side (C). Each data point represents a mean $\pm \operatorname{SEM}(n=4)$.

$\mathrm{Cl}^{-}$and $\mathrm{HCO}_{3}{ }^{-}$were removed, the naringenin-evoked $I_{\mathrm{sC}}$ was decreased by $98.21 \%$, $(\mathrm{n}=4, \mathrm{P}$ $<0.001$, Fig. 2C). To confirm that the results of the gluconate substitution experiments were reliable, different $\mathrm{Ca}^{2+}$ concentrations were added to the $\mathrm{Cl}^{-}$free $\mathrm{K}-\mathrm{H}$ solution. The results showed that naringenin could not obviously increase the $I_{\mathrm{SC}}$ in different $\mathrm{Ca}^{2+}$ concentrations of $\mathrm{Cl}^{-}$free $\mathrm{K}-\mathrm{H}$ solution ( $\mathrm{n}=4, \mathrm{P}<0.001$, Fig. 3). These results indicated that the response of naringenin to $\mathrm{Cl}^{-}$substitution was irrelevant to the lowering of free calcium in the bathing solution.

The $\mathrm{Cl}^{-}$channel blocker DPC (1 mM) (Fig. 4A) and CFTR inhibitor CFTRinh-172 (10 $\left.\mu \mathrm{M}\right)$ both strongly inhibited the naringenin-induced $I_{\mathrm{sC}}$ increase on the mucosal side, whereas subsequent application of ATP $(100 \mu \mathrm{M})$ also caused an obvious increase at the same sample (Fig. 4B). The naringenin-induced $I_{\mathrm{SC}}$ could not be changed by DIDS $(100 \mu \mathrm{M})$, whereas it was inhibited by subsequent application of CFTRinh-172 (Fig. 4C). The above results indicate that the change in $I_{\mathrm{SC}}$ induced by naringenin could be influenced, to a large extent, by CFTRdependent $\mathrm{Cl}^{-}$secretion.

To test what influenced the naringenin-induced $I_{\mathrm{sC}}$ on the basolateral side, $100 \mu \mathrm{M}$ bumetanide, a Na+ $\mathrm{K}^{+}-2 \mathrm{Cl}^{-}$cotransporter inhibitor, was added to the basolateral side and abolished the naringenin-induced $I_{\mathrm{SC}}$ increase (Fig. 5A). Further, the response to naringenin was strongly affected by basolateral addition of $\mathrm{BaCl}_{2}$, a $\mathrm{K}^{+}$channel inhibitor (Fig. 5B). The naringenin-induced $I_{\mathrm{SC}}$ could be abolished by adding bumetanide $(97.01 \%)$ and $\mathrm{BaCl}_{2}(97.96 \%)$ (Fig. 5C). The above results suggest that the $I_{\mathrm{SC}}$ response induced by naringenin is attributed to $\mathrm{K}^{+}$absorption on the basolateral side. The basolateral membrane $\mathrm{Na}^{+}-\mathrm{K}^{+}-2 \mathrm{Cl}^{-}$cotransporter and $\mathrm{K}^{+}$channel play important roles in maintaining the driving force for apical CFTRmediated chloride secretion.

\section{Involvement of cAMP in mediating the effect of naringenin}

It is well known that CFTR activated by cAMP induces a long-lasting stimulatory effect on $I_{\mathrm{SC}}$. The naringenin-induced $I_{\mathrm{sC}}$ is similar to a short circuit current reaction mediated 


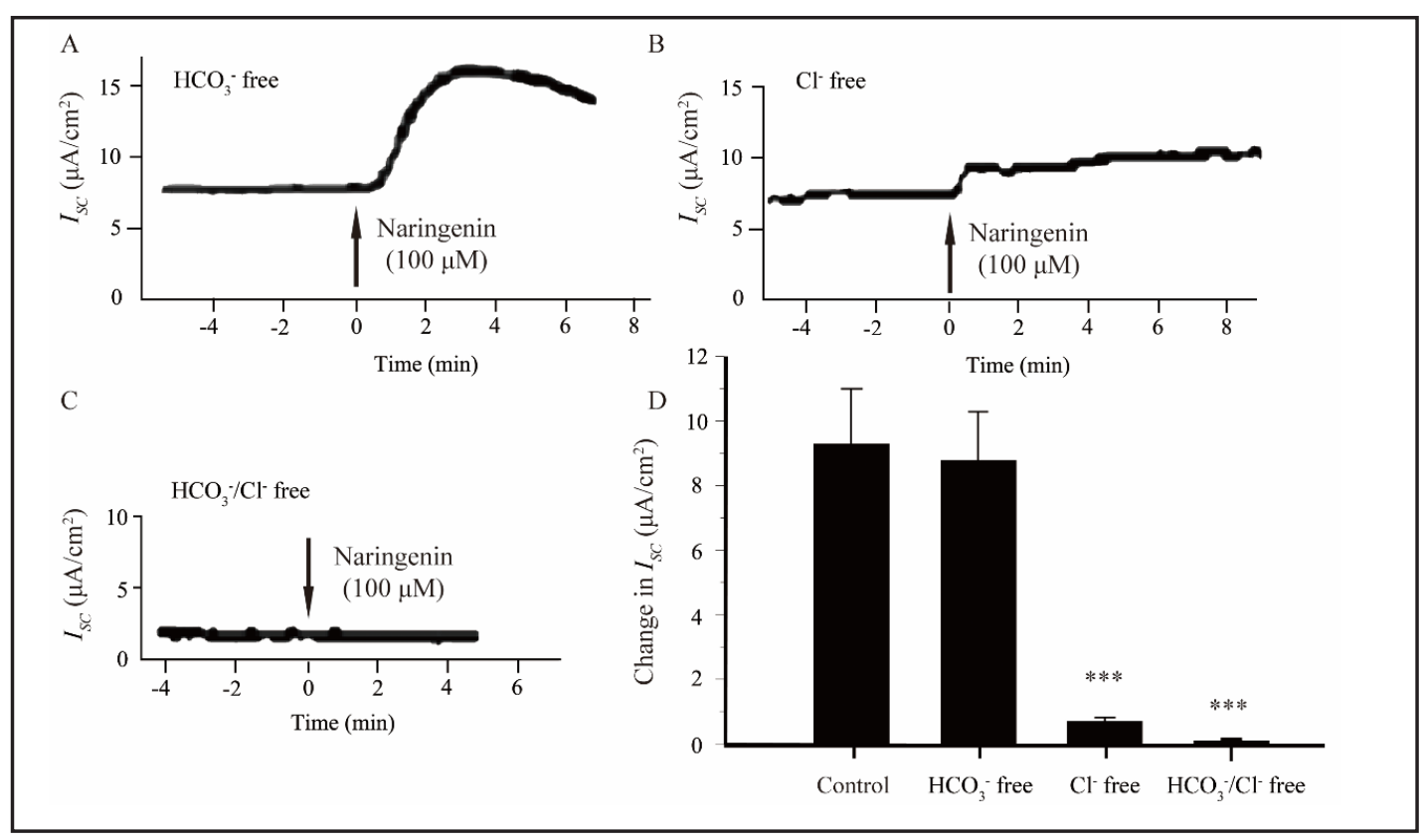

Fig. 2. Replacement of extracellular anions resulted in different $I_{S C}$ values induced by naringenin. Representative $\mathrm{I}_{\mathrm{SC}}$ recording with arrows indicating naringenin $(100 \mu \mathrm{M})$ added basolaterally in different $\mathrm{K}-\mathrm{H}$ solutions. $\mathrm{HCO}_{3}^{-}$free $\mathrm{K}-\mathrm{H}(\mathrm{A})$; $\mathrm{Cl}^{-}$free $\mathrm{K}-\mathrm{H}(\mathrm{B})$; $\mathrm{Cl}^{-} / \mathrm{HCO}_{3}^{-}$free $\mathrm{K}-\mathrm{H}(\mathrm{C})$; Comparison of the naringenininduced total charges transferred in various bathing solutions (D). Values are the mean \pm SEM (n $=4$, *** $\mathrm{P}<0.001$ vs. control).

by cAMP. After treatment with forskolin, an adenylate cyclase activator, was used to consume the intracellular adenylate cyclase, intracellular cAMP cannot be further elevated upon subsequent addition of cAMPelevating agents. IBMX, an inhibitor of phosphodiesterase, is used to inhibit degradation of intracellular cAMP. Pretreatment with forskolin abolished the $I_{\mathrm{SC}}$ increase induced by naringenin (Fig. 6A). Meanwhile, the naringenin-induced $I_{\mathrm{SC}}$ was attenuated by pretreatment with MDL-12330A (Fig. 6B), an inhibitor of adenyl cyclase, whereas sub-

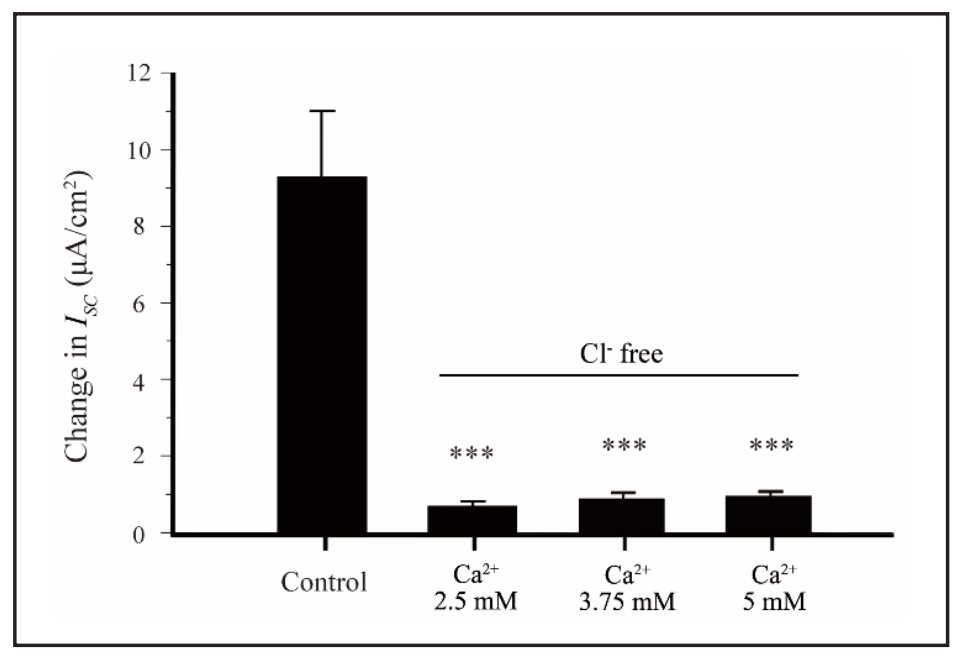

Fig. 3. Different concentrations of $\mathrm{Ca}^{2+}$ in $\mathrm{Cl}^{-}$free $\mathrm{K}-\mathrm{H}$ solutions resulted in the same $\mathrm{I}_{\mathrm{SC}}$ induced by naringenin $(100 \mu \mathrm{M})$. Comparison of the naringenin-induced total charges transferred in various bathing solutions. The values are the mean \pm SEM ( $\mathrm{n}=4, * * * \mathrm{P}<0.001$ vs. control). sequent application of ATP $(100 \mu \mathrm{M})$ caused an obvious increase. However, in the IBMX-induced $I_{\mathrm{SC}}$, naringenin could further obviously increase the $I_{\mathrm{SC}}$ (Fig. 6C). Statistical analysis showed that the naringenininduced $I_{\mathrm{SC}}$ was absolutely abrogated by pretreatment with forskolin $(90.23 \%)$ and MDL$12330 \mathrm{~A}(97.77 \%)$, but IBMX did not affect the $I_{\mathrm{SC}}$ induced by naringenin (Fig. 6D). In addition, in the naringenin-induced $I_{\text {SC }}$ response, forskolin (Fig. 7A) and IBMX (Fig. 7C) obviously increased the $I_{\mathrm{SC}}$. After naringenin pretreatment, the $I_{\mathrm{SC}}$ increase induced by forskolin 


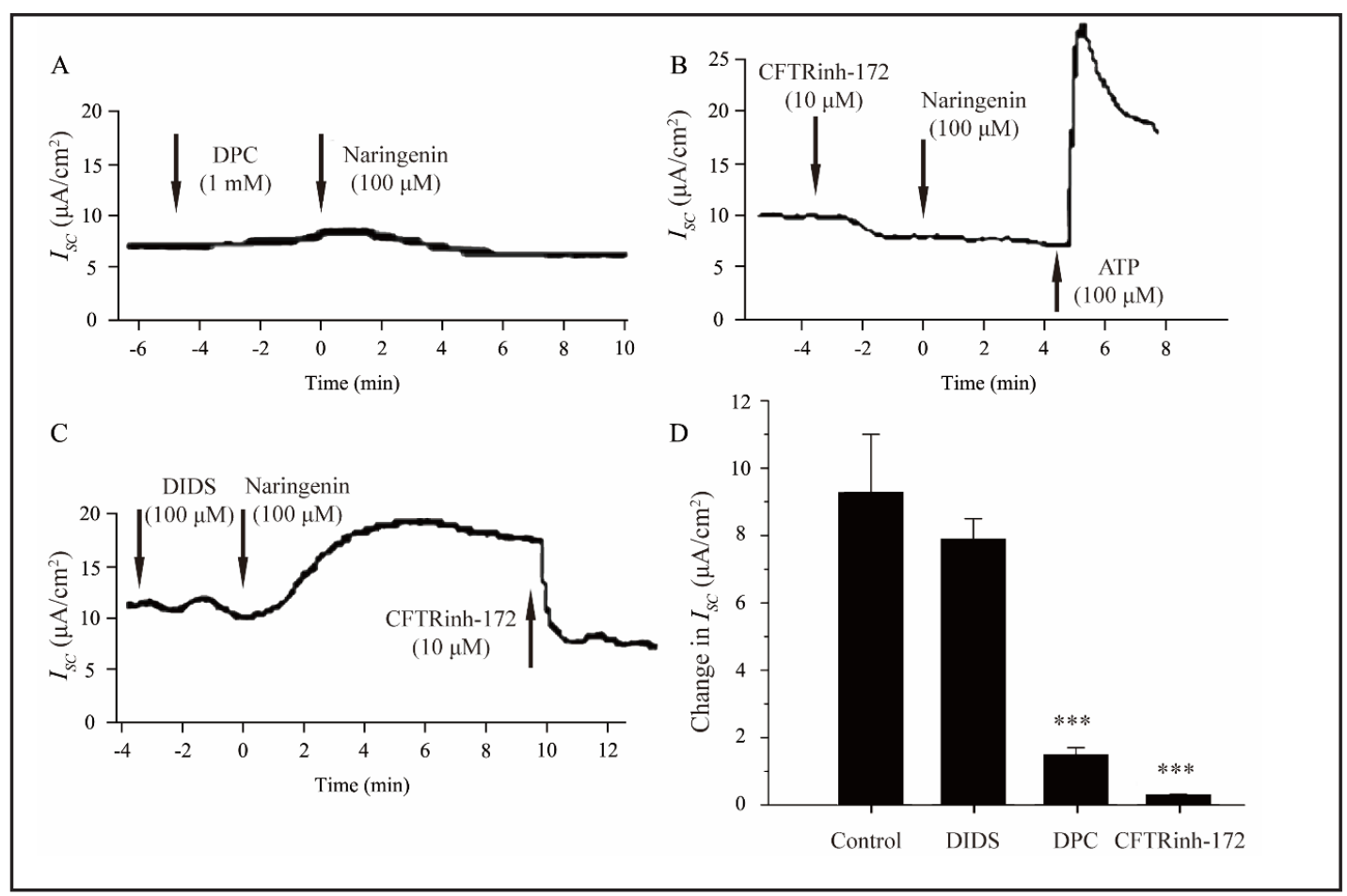

Fig. 4. Effect of different $\mathrm{Cl}^{-}$channel blockers and ATP on the naringenin-evoked $\mathrm{I}_{\mathrm{SC}}$ in the rat airway. Pretreatment of tissues with DPC $(1 \mathrm{mM})$ on the apical side, naringenin $(100 \mu \mathrm{M})$ could not induce an $\mathrm{I}_{\mathrm{SC}}$ increase (A). CFTRinh-172 $(10 \mu \mathrm{M})$ applied to the apical side of airway tissue inhibited the naringeninevoked $\mathrm{I}_{\mathrm{SC}}$, which was aroused by apical application of $100 \mu \mathrm{M}$ ATP (B). The naringenin-evoked $\mathrm{I}_{\mathrm{SC}}$ increases were not affected by pretreatment with DIDS $(100 \mu \mathrm{M})$ on the tissue apical side, but they were completely inhibited by $10 \mu \mathrm{M}$ CFTRinh-172 (C). Comparison of different $\mathrm{Cl}^{-}$channel blockers inhibiting the naringenininduced $\mathrm{I}_{\mathrm{SC}}$ increases on the apical side (D). The values are the mean \pm SEM ( $\mathrm{n}=4,{ }^{* * *} \mathrm{P}<0.001$ vs. control).

showed a significant decrease compared with the use of forskolin alone (Fig. 7B), while the IBMX-induced $I_{\text {SC }}$ increase showed no significant difference with itself (Fig. 7D). The above results suggest that CAMP is of critical importance in mediating chloride secretion and regulating CFTR on the apical side. Naringenin modulates the activity of CFTR by increasing adenylate cyclase activity rather than by directly inhibiting phosphodiesterase activity.

To rule out the possibility that naringenin acts on sub-epithelial interstitial cells of the airway to release a paracrine agent that alters the $I_{\mathrm{SC}}$ response of the airway epithelial cells, we supplemented the $I_{\mathrm{SC}}$ responses of Calu-3 cells with naringenin and forskolin addition (Fig. 8). The results showed that both naringenin and forskolin could increase $I_{S C}$, and the results were identical to the airway tissue experiment results. In the naringenin-induced $I_{\mathrm{SC}}$ response, forskolin obviously increased the $I_{S C}$, while on the basis of the forskolin-induced $I_{\mathrm{SC}}$ increase, naringenin could not further induce a change in the $I_{\mathrm{SC}}$. These experiments suggested that the $I_{\mathrm{SC}}$ response of the airway to naringenin did not act on sub-epithelial interstitial cells of the airway but directly acted on epithelial cells to stimulate $\mathrm{Cl}^{-}$secretion.

Before ELISAs, the primary cultured cells were authenticated as epithelial cells (Fig. 9). The data (Fig. 10) showed that the cAMP dependent pathway played a notable role in mediating the naringenin-induced response to regulate $\mathrm{Cl}^{-}$secretion. Under basal conditions (0.1\% DMSO), the intracellular cAMP content was $5.29 \pm 3.74 \mathrm{pmol} / \mathrm{mg}$ protein $(\mathrm{n}=3)$ in primary airway epithelial cells and $15.09 \pm 3.12 \mathrm{pmol} / \mathrm{mg}$ protein $(\mathrm{n}=3)$ in Calu- 3 cells. After adding naringenin at a concentration of $100 \mu \mathrm{M}$, the cAMP levels were $34.55 \pm 7.49 \mathrm{pmol} /$ mg protein $(\mathrm{n}=3)$ in primary airway epithelial cells and $45.56 \pm 1.85 \mathrm{pmol} / \mathrm{mg}$ protein $(\mathrm{n}$ = 3) in Calu-3 cells. IBMX, a phosphodiesterase inhibitor, was used to assess whether cAMP degradation contributed to the increase in cAMP concentration. It caused an enhancement 


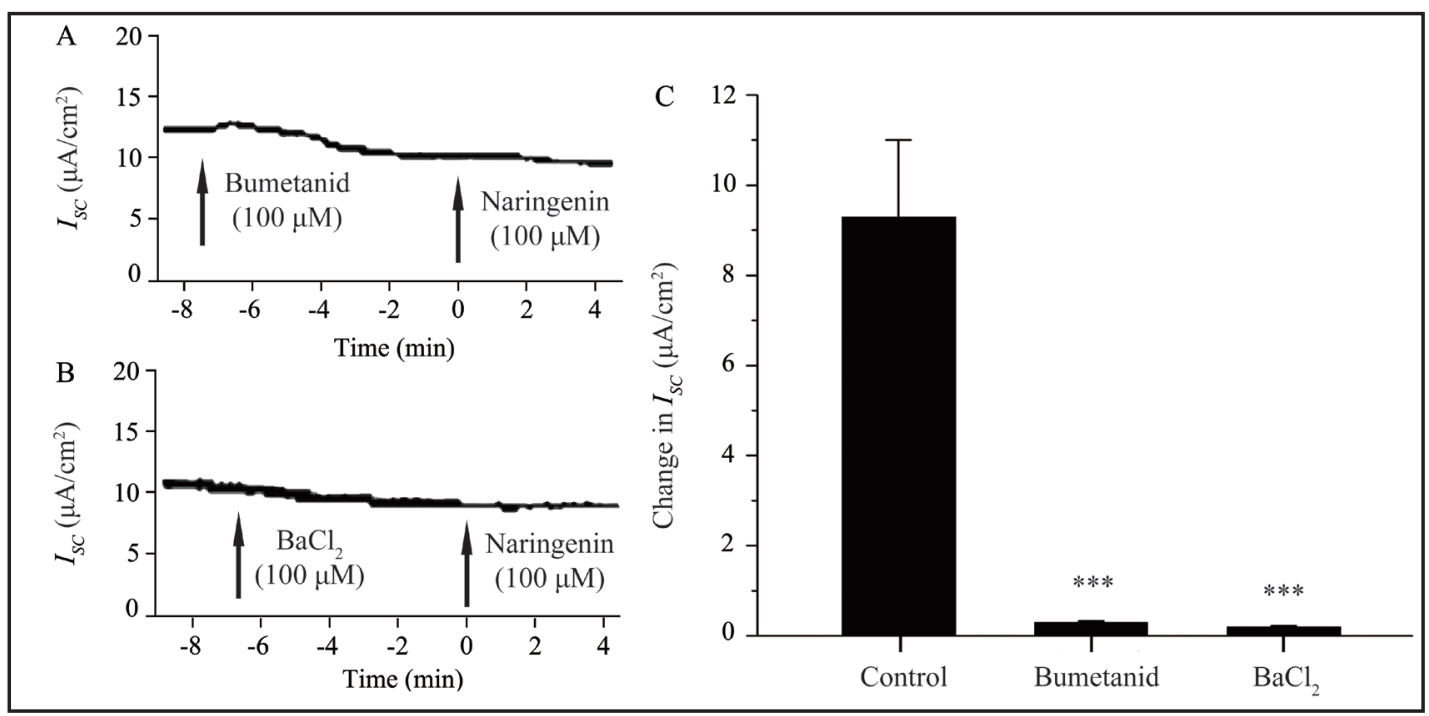

Fig. 5. Effect of bumetanide and $\mathrm{BaCl}_{2}$ on the naringenin-evoked $\mathrm{I}_{\mathrm{SC}}$ in rat airway. After pretreating tissues with bumetanide $(100 \mu \mathrm{M})$ on the basolateral side, naringenin $(100 \mu \mathrm{M})$ could not induce $\mathrm{I}_{\mathrm{SC}}$ increases $(\mathrm{A})$. $\mathrm{BaCl}_{2}(100 \mu \mathrm{M})$ applied to the basolateral side of the airway tissue inhibited the naringenin-evoked $\mathrm{I}_{\mathrm{SC}}(\mathrm{B})$. Comparison of the naringenin-induced $\mathrm{I}_{\mathrm{SC}}$ increases on the basolateral side inhibited by bumetanide and $\mathrm{BaCl}_{2}(\mathrm{C})$. The values are the mean $\pm \operatorname{SEM}\left(\mathrm{n}=4,{ }^{* * *} \mathrm{P}<0.001\right.$ vs. control).

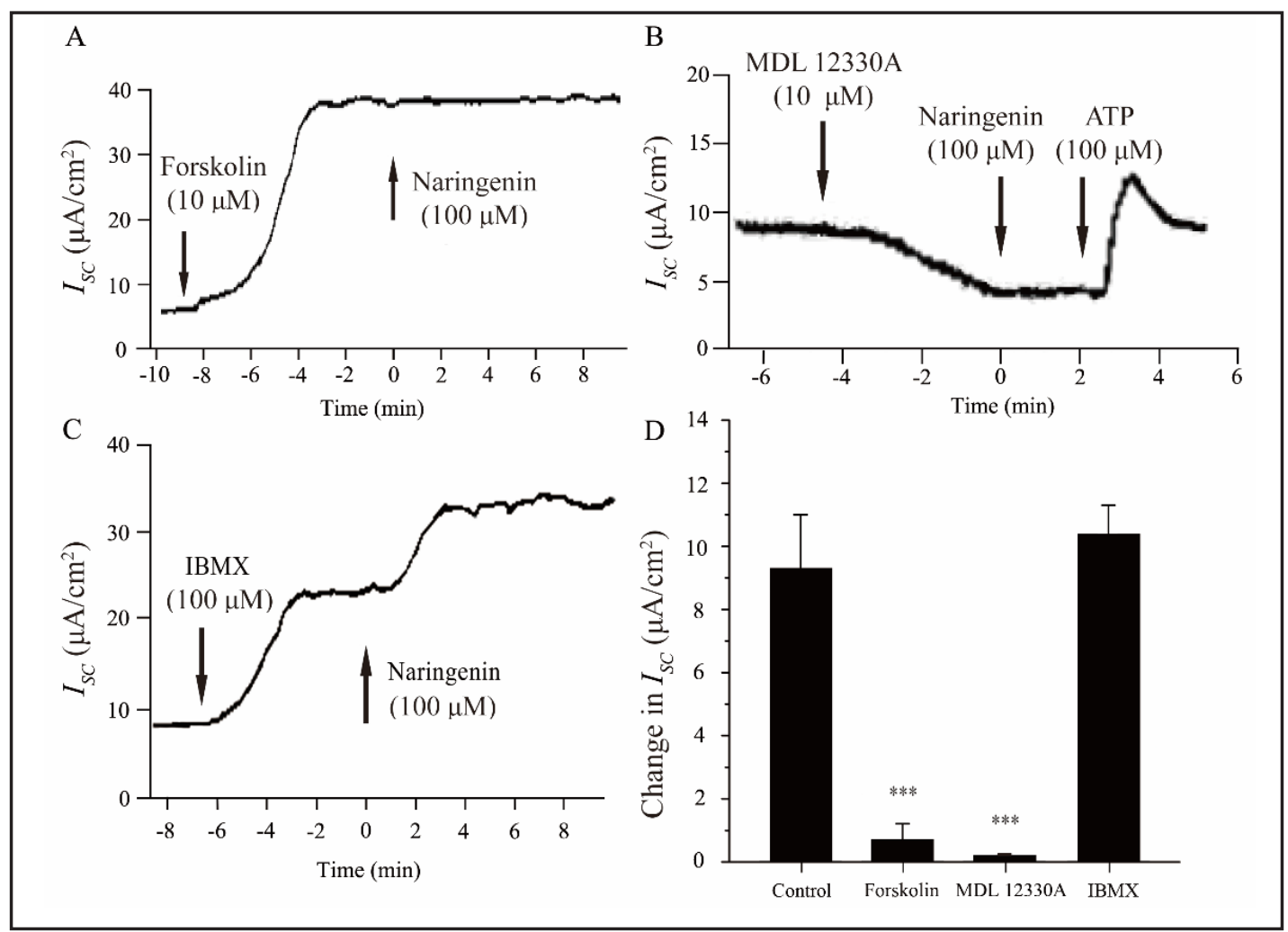

Fig. 6. Effect of forskolin, MDL-12330A and IBMX on the naringenin-evoked $\mathrm{I}_{\mathrm{SC}}$ in rat airway tissue. Pretreatment with forskolin $(10 \mu \mathrm{M})$ reduced the naringenin-induced $\mathrm{I}_{\mathrm{SC}}$ by $90.23 \%$ (A and D). Pretreatment with MDL-12330A $(10 \mu \mathrm{M})$ reduced the naringenin-induced $\mathrm{I}_{\mathrm{SC}}$ by $97.77 \%$ (B and D). Pretreatment with IBMX $(100 \mu \mathrm{M})$ could not reduce the naringenin-induced $\mathrm{I}_{\mathrm{SC}}$ increase, the increase of which showed no significant difference with using naringenin alone (C and D). The values are the mean \pm SEM $(n=4$, *** $\mathrm{P}<0.001$ vs. control). 


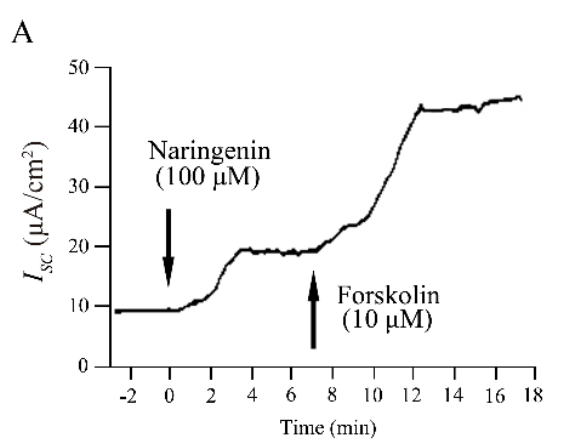

C

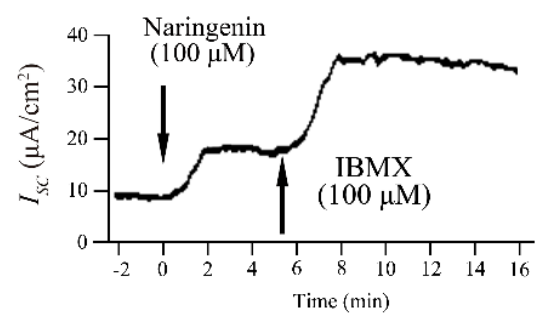

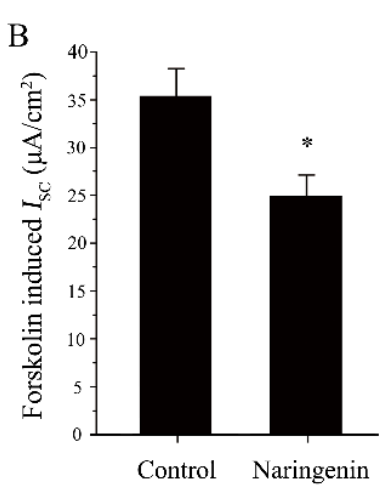

$\mathrm{D}$

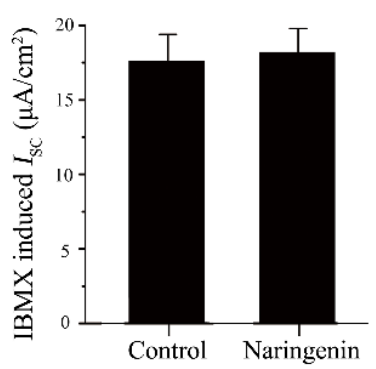

Fig. 7. $I_{\mathrm{SC}}$ response to naringenin followed by forskolin and IBMX addition on rat airway tissue. After pretreating tissues with naringenin $(100 \mu \mathrm{M})$, forskolin $(10 \mu \mathrm{M})$ could also induce $\mathrm{I}_{\mathrm{SC}}$ increases $(\mathrm{A})$. IBMX $(100 \mu \mathrm{M})$ applied to the airway tissue could not inhibit the naringenin-evoked $\mathrm{I}_{\mathrm{SC}}(\mathrm{C})$. The comparison of $\mathrm{I}_{\mathrm{SC}}$ increases between adding forskolin $(10 \mu \mathrm{M})(\mathrm{B})$, IBMX $(100 \mu \mathrm{M})(\mathrm{D})$ alone and naringenin $(100 \mu \mathrm{M})$ pretreatment. The values are the mean \pm SEM $(n=4)$.

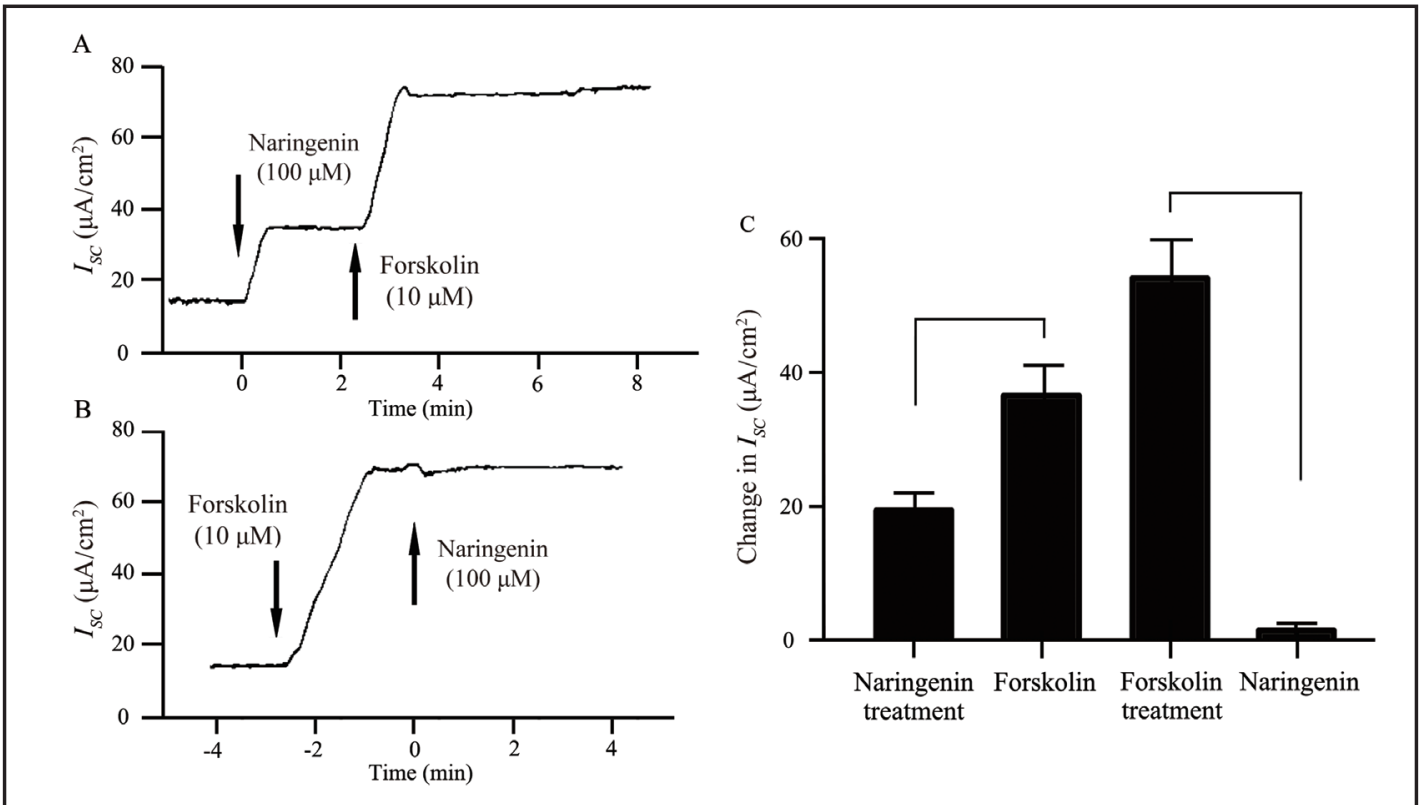

Fig. 8. Effect of naringenin and forskolin on $\mathrm{I}_{\mathrm{SC}}$ response in Calu-3 cells. After cells were pretreated with naringenin $(100 \mu \mathrm{M})$, forskolin $(10 \mu \mathrm{M})$ could also induce $\mathrm{I}_{\mathrm{SC}}$ increases $(\mathrm{A})$. Pretreatment with forskolin reduced the naringenin-induced $I_{S C}(B)$. The comparison of $I_{S C}$ increases between naringenin $(100 \mu \mathrm{M})$ pretreatment and forskolin $(10 \mu M)$ pretreatment $(C)$. The values are the mean \pm SEM $(n=4)$. 


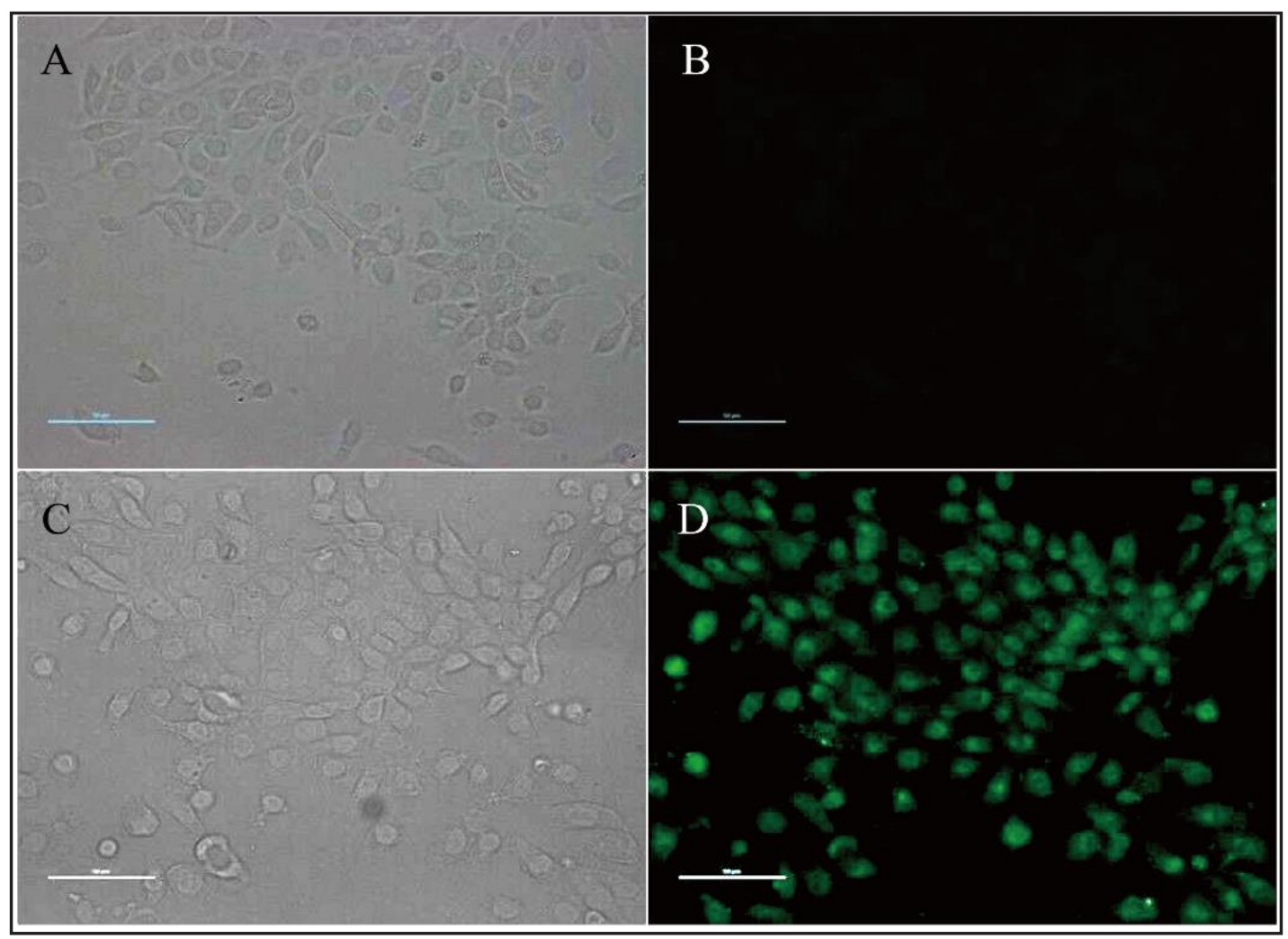

Fig. 9. Labeling primary cultured cells with anti-smooth muscle antibody (SMA) (A and B) and anti-keratin antibody (C and D) confirmed the primary airway epithelial cells.

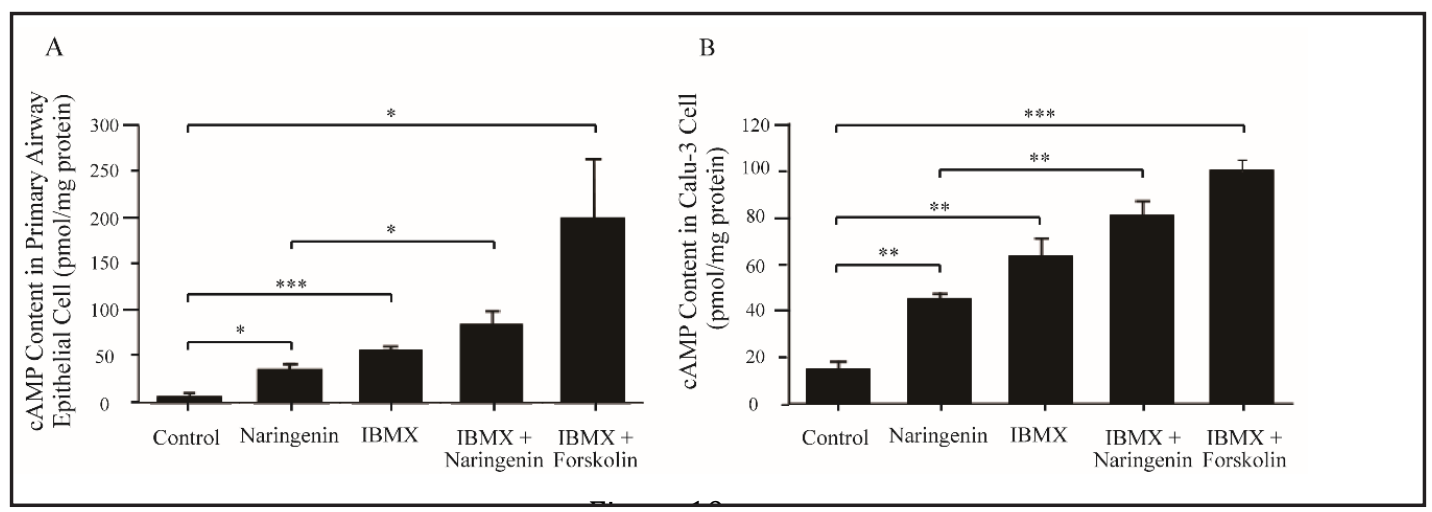

Fig. 10. Effect of naringenin on the endocellular cAMP level of rat primary airway epithelial cells (A) and Calu-3 cells (B). Contrast of the cAMP increase induced by naringenin $(100 \mu \mathrm{M})$, IBMX $(100 \mu \mathrm{M})$, and forskolin $(10 \mu \mathrm{M})$ with control. The values are the mean $\pm \operatorname{SEM}\left(\mathrm{n}=3,{ }^{*} \mathrm{P}<0.05,{ }^{* *} \mathrm{P}<0.01,{ }^{* * *} \mathrm{P}<0.001\right.$, vs. control).

in cAMP levels to $56.74 \pm 4.31 \mathrm{pmol} / \mathrm{mg}$ protein $(\mathrm{n}=3)$ in primary airway epithelial cells and $63.44 \pm 7.97 \mathrm{pmol} / \mathrm{mg}$ protein $(\mathrm{n}=3)$ in Calu-3 cells. In addition, incubation with naringenin $(100 \mu \mathrm{M})$ and IBMX $(100 \mu \mathrm{M})$ led to an obvious increase in cAMP levels to $84.65 \pm$ $14.33 \mathrm{pmol} / \mathrm{mg}$ protein ( $\mathrm{n}=3$, primary airway epithelial cells) and $81.28 \pm 6.09 \mathrm{pmol} / \mathrm{mg}$ protein ( $\mathrm{n}=3$, Calu-3 cells). Furthermore, IBMX $(100 \mu \mathrm{M})$ and forskolin $(10 \mu \mathrm{M})$ induced the highest increase in cAMP levels in primary airway epithelial cells $(198.80 \pm 66.47 \mathrm{pmol} / \mathrm{mg}$ protein $(n=3))$ and Calu-3 cells $(100.25 \pm 4.78 \mathrm{pmol} / \mathrm{mg}$ protein $(\mathrm{n}=3))$, to reference the naringenin contribution.

\section{KARGER}




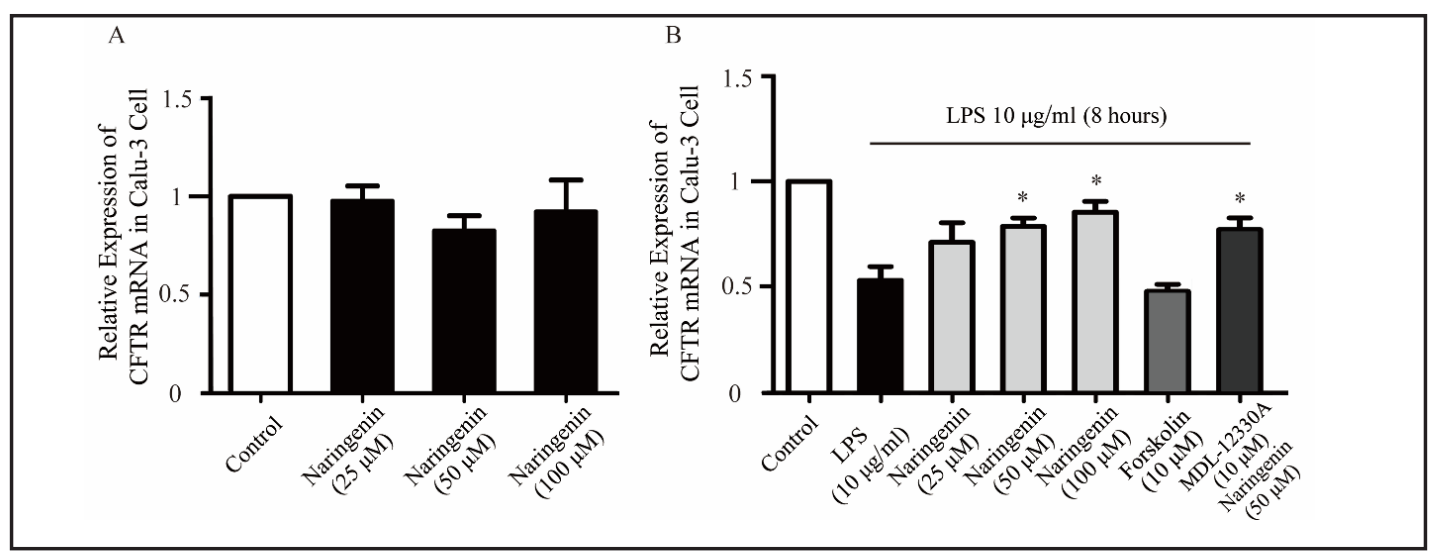

Fig. 11. Calu-3 cell CFTR mRNA expression in the presence of naringenin. Transcription of CFTR was determined by RT-qPCR, using $\beta$-actin as a housekeeper gene. Calu- 3 cells were treated without (A) or with (B) $10 \mu \mathrm{g} / \mathrm{ml}$ LPS for 8 hours ( $\mathrm{n}=3,{ }^{*} \mathrm{P}<0.05$, ${ }^{*} \mathrm{P}<0.01$ vs. control group (A)/LPS-treated group (B)). Without LPS stimulation, the relative expression of CFTR mRNA was not changed. However, CFTR mRNA expression was down-regulated when the sample was treated with LPS and significantly up-regulated by naringenin. The data are presented as the mean \pm SEM.

\section{Effect of naringenin on CFTR $m R N A$ expression}

To evaluate differences in CFTR mRNA expression in response to concentration changes of naringenin $(25 \mu \mathrm{M}, 50 \mu \mathrm{M}$ and $100 \mu \mathrm{M})$, Calu-3 cells were treated for 8 hours. Compared with control cells, the qRT-PCR assay showed that naringenin incubation did not induce a significant change (Fig. 11A) at any concentration $(n=3, p>0.05)$. In addition, after CFTR expression in Calu-3 cells was decreased by LPS stimulation, various concentrations of naringenin $(25 \mu \mathrm{M}, 50 \mu \mathrm{M}$ and $100 \mu \mathrm{M})$ were added to the cell medium, and the cells were incubated for 8 hours to detect the effect of naringenin on CFTR mRNA expression (Fig. 11B). When cells were treated with LPS $(10 \mu \mathrm{g} / \mathrm{ml})$ for 8 hours, CFTR mRNA expression was decreased by 1.9 -fold compared with the control $(n=3, p<0.01)$. All concentrations of naringenin had positive effects on the mRNA expression of CFTR after cells were stimulated by LPS, but only $50 \mu \mathrm{M}$ and $100 \mu \mathrm{M}$ naringenin $(\mathrm{n}=3, \mathrm{p}<0.05)$ had a significant difference in the LPS treatment group. Forskolin did not change the decrease in CFTR mRNA expression induced by LPS. MDL12330A did not inhibit the naringenin recovery of CFTR mRNA expression in the presence of LPS.

\section{Discussion}

The present study aimed to analyze the CFTR activation and expression regulated by naringenin and to develop an effective and comprehensive treatment strategy for sputum. CFTR, a potential primary pathway that regulates periciliary fluid balance [2] and inflammatory signaling $[14,15,16]$ in airway epithelium, could potentially be used as a therapeutic target for sputum clinical therapies. Interest in the discovery of CFTR activators as potential small molecular targets has risen in recent years. Naringenin, a small molecule derived from plant-based compounds, has been generally used in respiratory diseases for relieving cough, expectoration and reducing lung infection $[6,17]$. A previous study found that naringenin, a major metabolite of naringin, was able to stimulate cAMP-dependent $\mathrm{Cl}^{-}$secretion across human colonic epithelia [12]. Apigenin, having a common 2-phenyl-g-benzopyron structure with naringenin, could activate CFTR on Calu-3 cells owing to its specific structural components [18]. Nobiletin, a citrus flavonoid, can stimulate CFTR-mediated $\mathrm{Cl}^{-}$secretion by adenylate cyclase- and cAMP/PKA-dependent pathways across bronchial epithelia 
Shi et al.: Effect of Naringenin on CFTR

[19]. Trimethoxyflavone and other flavones can also active CFTR both in vitro and in vivo [20]. It has been suggested that naringenin may regulate $\mathrm{Cl}^{-}$secretion and fluid transport in cAMP-mediated CFTR function in airway epithelia. The current study initially proves that naringenin has the ability to trigger cAMP-dependent $\mathrm{Cl}^{-}$secretion via CFTR transportation in airway epithelia and regulate CFTR expression in an LPS-induced CFTR down-regulation model in vivo, ultimately producing an expectorant effect.

To test whether naringenin has the ability to regulate CFTR activation, normal rat airway epithelium was used in the $I_{\mathrm{SC}}$ test. The present study showed that naringenin could dose-dependently stimulate a sustained increase in $I_{\mathrm{SC}}$ (Fig. 1), generating cAMP-dependent CFTR-mediated $\mathrm{Cl}^{-}$secretion across rat airway epithelia. We used $100 \mu \mathrm{M}$ naringenin in subsequent experiments because it was the most suitable value that was close to the naringenin $\mathrm{EC}_{50}$ value of $71.49 \pm 10.76 \mu \mathrm{M}$. At this concentration, naringenin significantly stimulated an increase in the short-circuit current value, thus facilitating the records and measurements of follow-up experiments. The Hill coefficient was 1.84, which was significantly greater than 1 . This suggested that there was a positive cooperativity between naringenin molecules. After binding to the receptor, naringenin may improve the receptor binding affinity to other naringenin molecules. When $\mathrm{Cl}^{-}$was eliminated from the bathing $\mathrm{K}-\mathrm{H}$ solution, the naringenin-induced $I_{\mathrm{sC}}$ was greatly attenuated (Fig. 2), which was due largely to transmembrane $\mathrm{Cl}^{-}$secretion from the apical side rather than $\mathrm{HCO}_{3}^{-}$secretion and electrogenic $\mathrm{Na}^{+}$absorption. Using a $\mathrm{Cl}^{-}$channel blocker to screen apical $\mathrm{Cl}^{-}$channels that were activated by naringenin showed that both the $\mathrm{Cl}^{-}$channel blocker DPC and the CFTR inhibitor CFTRinh-172 could interdict the naringenin-induced $I_{\mathrm{SC}}$, but the calcium-activated chloride channel (CaCC) blocker DIDS had no effect on it (Fig. 4). These results clearly established that naringenin has the ability to induce a continuous $I_{\mathrm{SC}}$ response by stimulating CFTR-mediated $\mathrm{Cl}^{-}$secretion on the apical side.

Previous studies have shown that the $\mathrm{Na}^{+}-\mathrm{K}^{+}-2 \mathrm{Cl}^{-}$cotransporter provides the driving force for apical chloride secretion across epithelia. In addition, $\mathrm{K}^{+}$channels also play an important role in this process to expel $\mathrm{K}^{+}$, which is transported by the $\mathrm{Na}^{+}-\mathrm{K}^{+}-2 \mathrm{Cl}^{-}$cotransporter from the cells to preserve $\mathrm{K}^{+}$concentration stability [21]. The $\mathrm{K}^{+}$channel blocker $\mathrm{BaCl}_{2}$ and the $\mathrm{Na}^{+}-\mathrm{K}^{+}-2 \mathrm{Cl}^{-}$cotransporter inhibitor bumetanide were used to detect the naringenin-induced current on the basolateral membrane. As predicted, the increase of current caused by naringenin was sensitive to bumetanide and $\mathrm{BaCl}_{2}$ (Fig. 5). These results indicate that the effect of naringenin on CFTR function is supported by $\mathrm{Na}^{+}-\mathrm{K}^{+}-2 \mathrm{Cl}^{-}$cotransporters and $\mathrm{K}^{+}$ channels.

It has been confirmed that the cAMP signaling pathway can regulate $\mathrm{Cl}^{-}$transport across a wide range of tight epithelia. Cytosolic cAMP, a second messenger, regulates CFTR activation via protein kinase A (PKA) [21-24]. The adenylate cyclase activator forskolin stimulated the cAMP-dependent secretion, which generates a maximum current, while subsequent addition of naringenin could not further increase the current. In the naringenin-induced $I_{\mathrm{SC}}$ response, forskolin could also obviously increase the $I_{\mathrm{SC}}$, while the increase was significantly lower than that observed when using forskolin alone. The difference between the increases was approximately equal to the value of the naringenin-induced $I_{\mathrm{SC}}$. Pretreatment with an adenylate cyclase inhibitor (MDL12330A) had an inhibitory effect on the naringenin-induced $I_{\mathrm{SC}}$, while pretreatment with a phosphodiesterase inhibitor (IBMX) did not affect the $I_{\mathrm{SC}}$ increase induced by naringenin. In addition, the $I_{\mathrm{SC}}$ increase of airway epithelia was not significantly different when adding IBMX before or after naringenin. These results suggest the possibility that the function of naringenin is similar to that of forskolin in the intracellular second messenger pathway, which can be impeded by MDL12330A, rather than the IBMXassociated pathway (Fig. 6 and 7). In addition, ELISA measurement demonstrated that cAMP production exhibited a noteworthy increase in primary rat airway epithelial cells and Calu-3 cells induced by naringenin. Simultaneously treating cells with naringenin and IBMX further enhanced the cAMP level when compared to naringenin-only treatment. Moreover, forskolin also further increased cAMP production compared with naringenin in the presence of IBMX (Fig. 10). These results showed that naringenin modulated the activity of CFTR by increas-

\section{KARGER}


Shi et al.: Effect of Naringenin on CFTR

ing adenylate cyclase activity rather than by directly inhibiting phosphodiesterase activity. Naringenin could increase the cAMP content by promoting cAMP formation rather than by inhibiting cAMP degradation.

It is commonly known that Akt is a key mediator of signal transduction in CFTR synthesis $[25,26]$. LPS can bind to Toll-like receptor 4 (TLR4) and phosphorylate Akt to activate the phosphoinositide3-kinase (PI3K)-Akt pathway, which results in down-regulation of CFTR expression [27, 28]. This regulation can be abrogated by LY294002 (a PI3K/Akt inhibitor) [28]. Calu-3 cells isolated from human airway adenocarcinoma have high expression of CFTR in the apical membrane and selectively secrete $\mathrm{Cl}^{-}$to physiologically regulate serous secretion. Culturing Calu-3 cells with naringenin for 8 hours did not significantly increase the CFTR mRNA expression in any of the concentration tests. Compared with non-LPS treatment, an increase in CFTR expression was observed in the LPS-induced CFTR down-regulation model induced by naringenin stimulation. After LPS was incubated with Calu-3 cells for 8 hours, CFTR expression was significantly decreased, while naringenin dose-dependently enhanced the CFTR mRNA expression. Moreover, the middle and high dose of naringenin significantly increased CFTR expression. Relatively, forskolin had no effect on LPS-induced CFTR downregulation in Calu-3 cells. Furthermore, MDL12330A could not inhibit the naringenin recovery of CFTR mRNA expression in the presence of LPS. (Fig. 11). The results suggest that naringenin exerts its expectorant function by increasing CFTR expression while organismal CFTR expression was seriously disrupted, but it has no effect on normal cells. However, the intracellular cAMP content did not influence the regulation of CFTR mRNA by naringenin. In the CFTR mRNA expression process, expression regulation is affected by many factors, such as the abundance of miR-138 (a type of microRNA) [29], activation of NF- $\mathrm{BB}$ [30], activation of JAK2 via the JAK/STAT pathway [31] and activation of vasopressin [32]. In our study, naringenin increased the intracellular cAMP content, which was what forskolin did. However, separate administration of naringenin and forskolin failed to affect the expression of CFTR mRNA, indicating that the elevation of the cAMP content could not regulate the expression of CFTR mRNA. We speculated that naringenin suppressed LPS-induced down-regulation of CFTR mRNA through other signaling pathways, although the underlying mechanism needs further investigation. In brief, naringenin can both modulate the activity of CFTR via the cAMP pathway and rehabilitate CFTR expression when CFTR expression in the organism is suppressed.

The bioavailability of naringenin in rats was $39.8 \%$. When rats were orally administered naringenin at a dose of $350 \mathrm{mg} / \mathrm{kg}$, the plasma concentration of the drug reached a maximum value of $45200 \mathrm{ng} / \mathrm{ml}(166 \mu \mathrm{M})$ after 4 hours [33]. It was not the minimum effective concentration of naringenin used for in vivo experiments. In our in vivo expectorant experiments, naringenin could enhance tracheal phenol red output when rats were orally administered naringenin above a dose of $30 \mathrm{mg} / \mathrm{kg}$ [6]. Correspondingly, according to previous experimental results, the maximum plasma concentration value was $14.23 \mu \mathrm{M}$. The dose-response curve showed that naringenin stimulated $\mathrm{Cl}^{-}$secretion when the concentration was higher than $20 \mu \mathrm{M}$, which was in close proximity to $14.23 \mu \mathrm{M}$. This result confirmed the reliability of the in vivo experiment. However, the current study cannot provide a distribution ratio of naringenin in airway tissue, and therefore, a more accurate oral dosage cannot be calculated. Moreover, the above dosage is calculated on the basis of the maximum value, which neglects the maintenance period of the concentration in airway tissue, and thus, this only serves as a reference. In subsequent studies, we will analyze the drug efficacy curve and pharmacodynamic data to make a more reasonable clinical dose target for airway tissue.

\section{Conclusion}

In conclusion, this study indicated that naringenin has a potent effect on CFTR expression in an LPS-induced CFTR down-regulation model, which is supported by $\mathrm{Na}^{+}-\mathrm{K}^{+}-2 \mathrm{Cl}^{-}$cotransporters and $\mathrm{K}^{+}$channels on the basolateral membrane and simultaneously regulated 
Shi et al.: Effect of Naringenin on CFTR

by intracellular cAMP. The results indicate the mechanism by which naringenin provides a potential treatment strategy for sputum.

\section{Acknowledgements}

The work was supported by the National Natural Science Foundation of China (grant number 81374041).

\section{Disclosure Statement}

The authors declare that they have no conflicts of interest.

\section{References}

1 Derichs N, Jin BJ, Song Y, Finkbeiner WE, Verkman AS: Hyperviscous airway periciliary and mucous liquid layers in cystic fibrosis measured by confocal fluorescence photobleaching. FASEB J 2011;25:2325-2332.

-2 Rowe SM, Miller S, Sorscher EJ: Cystic Fibrosis. New Engl J Med 2005;352:1992-2001.

-3 Ramsey BW, Davies J, McElvaney NG, Tullis E, Bell SC, Dřevínek P, Griese M, McKone EF, Wainwright CE, Konstan MW, Moss R, Ratjen F, Sermet-Gaudelus I, Rowe SM, Dong Q Rodriguez S, Yen K, Ordoñez C, Elborn JS: A CFTR potentiator in patients with Cystic Fibrosis and the G551D mutation. New Engl J Med 2011;365:1663-1672.

4 Tarran R, Button B, Picher M, Paradiso AM, Ribeiro CM, Lazarowski ER, Zhang L, Collins PL, Pickles RJ, Fredberg JJ, Boucher RC: Normal and Cystic Fibrosis airway surface liquid homeostasis: The effects of phasic shear stress and viral infections. J Biol Chem 2005;280:35751-35759.

5 Pilewski JM, Frizzell RA: Role of CFTR in airway disease. Physiol Rev 1999;79:S215-S255.

-6 Lin BQ, Li PB, Wang YG, Peng W, Wu Z, Su WW, Ji H: The expectorant activity of naringenin. Pulm Pharmacol Ther 2008;21:259-263.

7 Bok SH, Jeong TS, Bae KH, Park YB, Choi MS, Moon SS, Kwon YK, Lee ES, Hyun BH, Choi YK, Lee CH, Lee JS, Son KH, Kwon BM, Kim YK, Choi D, Kim SU, Hwang I, Ahn JA, Park YB, Kim HS, Choe SC: Naringin and naringenin as inhibitors of acyl CoA-cholesterol-o-acyltransferase. US Pat 2000;6165984.

8 Jeon SM, Kim HK, Kim HJ, Do GM, Jeong TS, Park YB, Choi MS: Hypocholesterolemic and antioxidative effects of naringenin and its two metabolites in high-cholesterol fed rats. Transl Res 2007;149:15-21.

-9 Shi Y, Dai J, Liu H, Li RR, Sun PL, Du Q, Pang LL, Chen Z, Yin KS: Naringenin inhibits allergen-induced airway inflammation and airway responsiveness and inhibits $\mathrm{NF}^{-} \mathrm{B}$ activity in a murine model of asthma. Can J Physiol Pharm 2009;87:729-735.

10 Yang J, Li Q, Zhou XD, Kolosov VP, Perelman JM: Naringenin attenuates mucous hypersecretion by modulating reactive oxygen species production and inhibiting $\mathrm{NF}_{\mathrm{K}} \mathrm{B}$ activity via EGFR-PI3K-Akt/ERK MAPKinase signaling in human airway epithelial cells. Mol Cell Biochem 2011;351:29-40.

-11 Yu H, Chen S, Yang Z, Pan A, Zhang G, Shan J, Tang X, Zhou W: Trimethyltin chloride induced chloride secretion across rat distal colon. Cell Biol Int 2009;34:99-108.

$\checkmark 12$ Yang ZH, Yu HJ, Pan A, Du JY, Ruan YC, Ko WH, Chan HC, Zhou WL: Cellular mechanisms underlying the laxative effect of flavonol naringenin on rat constipation model. PLoS One 2008;3:e3348.

13 Cuthbert AW, MacVinish LJ: Mechanisms of anion secretion in Calu-3 human airway epithelial cells by 7, 8-benzoquinoline. Br J Pharmacol 2003;140:81-90.

14 Vij N, Mazur S, Zeitlin PL: CFTR is a negative regulator of $\mathrm{NF}_{\mathrm{K}} \mathrm{B}$ mediated innate immune response. PLoS One 2009; 4:e4664.

15 Gao Z, Su X: CFTR regulates acute inflammatory responses in macrophages. QJM 2015;108:951-958.

16 Wang H, Cebotaru L, Lee HW, Yang Q, Pollard BS, Pollard HB, Guggino WB: CFTR Controls the Activity of NF$\kappa B$ by Enhancing the Degradation of TRADD. Cell Physiol Bioch 2016;40:1063-1078. 


\section{Cellular Physiology Cell Physiol Biochem 2017;44:1146-1160

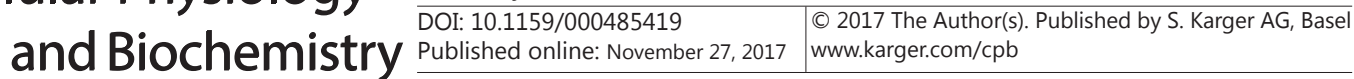

Shi et al.: Effect of Naringenin on CFTR

17 Yu DH, Ma CH, Yue ZQ Yao X, Mao CM: Protective effect of naringenin against lipopolysaccharide-induced injury in normal human bronchial epithelium via suppression of MAPK signaling. Inflammation 2015;38:195-204.

18 Illek B, Lizarzaburu ME, Lee V, Nantz MH, Kurth MJ, Fischer H: Structural determinants for activation and block of CFTR-mediated chloride currents by apigenin. Am J Physiol-Cell Ph 2000;279:C1838-C1846.

19 Hao Y, Cheung CS, Yip WC, Ko WH: Nobiletin Stimulates Chloride Secretion in Human Bronchial Epithelia via a cAMP/PKA-Dependent Pathway. Cell Physiol Biochem 2015;37:306-320.

-20 Fischer H, Illek B: Activation of the CFTR $\mathrm{Cl}^{-}$channel by trimethoxyflavone in vitro and in vivo. Cell Physiol Biochem 2008;22:685-692.

-21 Pondugula SR, Kampalli SB, Wu T, De Lisle RC, Raveendran NN, Harbidge DG, Marcus DC: cAMP-stimulated $\mathrm{Cl}^{-}$secretion is increased by glucocorticoids and inhibited by bumetanide in semicircular canal duct epithelium. BMC Physiology 2013;13:6.

22 Zegarra-Moran O, Galietta LJV: CFTR pharmacology. Cell Mol Life Sci 2017;74:117-128.

23 Monterisi S, Casavola V, Zaccolo M: Local modulation of cystic fibrosis conductance regulator: cytoskeleton and compartmentalized cAMP signalling. Br J Pharmacol 2013;169:1-9.

24 Collawn JF, Matalon S: CFTR and lung homeostasis. Am J Physiol Lung Cell Mol Physiol 2014;307:L917L923.

25 Roux J, Carles M, Koh H, Goolaerts A, Ganter MT, Chesebro BB, Howard M, Houseman BT, Finkbeiner W, Shokat KM, Paquet AC, Matthay MA, Pittet JF: Transforming growth factor 1 inhibits Cystic Fibrosis Transmembrane Conductance Regulator-dependent cAMP-stimulated alveolar epithelial fluid transport via a phosphatidylinositol 3-Kinase-dependent mechanism. J Biol Chem 2010;285:4278-4290.

26 Hsieh AC, Truitt ML, Ruggero D: Oncogenic AKTivation of translation as a therapeutic target. Br J Cancer 2011;105:329-336.

-27 He Z, Gao Y, Deng Y, Li W, Chen Y, Xing S, Zhao X, Ding J, Wang X: Lipopolysaccharide induces lung fibroblast proliferation through Toll-like receptor 4 signaling and the phosphoinositide3-kinase-Akt pathway. PLoS One 2012; 7:e35926.

28 Yang Y, Cheng Y, Lian QQ, Yang L, Qi W, Wu DR, Zheng X, Liu YJ, Li WJ, Jin SW, Smith FG: Contribution of CFTR to alveolar fluid clearance by lipoxin A4 via PI3K/Akt pathway in LPS-induced acute lung injury. Mediat Inflamm 2013;2013:862628.

-29 Ramachandran S, Karp PH, Jiang P, Ostedgaard LS, Walz AE, Fisher JT, Keshavjee S, Lennox KA, Jacobi AM, Rose SD, Behlke MA, Welsh MJ, Xing Y, McCray PB Jr: A microRNA network regulates expression and biosynthesis of wild-type and $\Delta \mathrm{F} 508$ mutant cystic fibrosis transmembrane conductance regulator. P Natl Acad Sci USA 2012;109:13362-13367.

-30 Brouillard F, Bouthier M, Leclerc T, Clement A, Baudouin-Legros M, Edelman A: $\mathrm{NF}_{\mathrm{K}} \mathrm{B}$ Mediates Up-regulation of CFTR Gene Expression in Calu-3 Cells by Interleukin-1ß. Biol Chem 2001;276: 9486-9491.

31 Kulka M, Dery R, Nahirney D, Duszyk M, Befus AD: Differential Regulation of Cystic Fibrosis Transmembrane Conductance Regulator by Interferon $\gamma$ in Mast Cells and Epithelial Cells. J Pharmacol Exp Ther 2005;315:563-570.

-32 de Lemos Barbosa CM, Souza-Menezes J, Amaral AG, Onuchic LF, Cebotaru L, Guggino WB, Morales MM: Regulation of CFTR Expression and Arginine Vasopressin Activity Are Dependent on Polycystin-1 in Kidney-Derived Cells. Cell Physiol Biochem 2016;38:28-39.

33 Fang TZ: Studies on Pharmacodynamics and Pharmacokinetics of Naringenin. Guangzhou, Sun Yat-sen University, 2005 (in Chinese). 